\title{
PARTHENOGENESIS AND THE INHERITANCE OF COLOR PATTERNS IN THE GROUSE LOCUST, TELMATETTIX AZTECUS SAUSSURE'
}

\author{
ROBERT K. NABOURS AND BERTHA SNYDER \\ Kansas State A gricultural College, Manhattan, Kansas
}

Received July 25, 1927

\section{MATERIAL AND METHODS}

Specimens of grouse locusts, identified by Doctor A. N. Caudell as Telmatettix aztecus Saussure, were secured along Shoal Creek, Austin, Texas, in August, 1922. By breeding analyses it was determined that there were four elementary patterns as follows: (1) A mottled gray closely resembling the $+/+$ of Apotettix eurycephalus (NABours 1925), and the ensemble of indistinguishable factors responsible for it, are represented by the symbol $+/+;(2)$ a dense black extending over the anterior pronotum and on the femora of the jumping legs is indicated by the letters $\mathrm{Bl}$; (3) a grayish white over the anterior pronotum and lateral lobes, resembling $C$, of Paratettix texanus (NABOURs 1917), although the posterior pronotum and legs are quite yellow, is represented by the letter $C$; (4) a dark greenish gray over the pronotum, including vertex, eyes and femora, with lighter lateral lobes, ranging almost to white, is designated by the letter $H$. In October, 1923, new specimens were secured from the same region, along Shoal Creek, and these included a new pattern; (5) a dull brick red covering the vertex, eyes, pronotum and posterior femora. This is designated by the letter $R$.

In January, 1923, Mr. Davis sent some specimens of this species from Pasadena, California. Only two individuals, females $+/+$ and $+/ C$, respectively, lived to be mated. They both produced offspring from males of the Texas stock. None of the progeny from the $+/+$, Pasadena female, was bred further. Three individuals from the $+/ C$ female (Pasadena) were bred and their progenies were widely used in later matings. It is to be noted, however, that none of the females producing parthenogenetic offspring, described farther on, had an ancestry which traced back to either of these Pasadena females.

All adult individuals of this species (Telmatettix aztecus) have had long wings and pronota, as against $P$. texanus and $A$. eurycephalus, individuals of which frequently have had short wings and pronota (NABours 1914, 1917, 1925).

\footnotetext{
${ }^{1}$ Contribution No, 96 from the Department of Zoology, Agricultural Experiment Station, Kansas State Agricultural College.
} 
They were bred casually and in small numbers during the year 1922-23, rather intensely and in considerable numbers in 1923-24, and only in small numbers since (till 1927).

They are bred in the greenhouse, and the mating jars used are the regular $8^{\prime \prime} \times 12^{\prime \prime}$ glass cylinders set in pots of earth and covered with screen wire lids. The food, consisting mainly of the filamentous algae, is placed on small earthern pots partly buried upside down in the soil (Nabours 1914, 1925).

The length of time required for breeding a generation varies with the time of the year and conditions of environment, the best season being the spring and early summer months. On the average, four succeeding generations a year may be bred in the greenhouse at Manhattan, Kansas. On hatching, the young are transferred, about 25 each, to larger similar cages. When of sufficient size for the color patterns to be easily distinguished, preferably during the third instar, they are recorded. As they become adult, the desired matings are made, and those remaining are again recorded, and preserved in 95 percent alcohol, in glass tubes sealed with a torch.

The experimental breeding of this species is much more difficult than is that of $P$. texanus and still more arduous than of $A$. eurycephalus. A large proportion of the matings are not productive, due usually to the early death of one or both individuals. During the whole period 1922-27, only 116 of the 187 matings made were productive. During the one year of most intensive breeding, May, 1923, to June, 1924, only 53.9 percent of the matings were productive; the range throughout the months of that year is indicated in table 1.

TABLE 1

Matings made compared with number productive-year 1923-24.

\begin{tabular}{l|c|c}
\hline \multicolumn{1}{|c|}{ MONTH } & MATINGS MADE & 2 \\
\hline June & 4 & 1 \\
July & 2 & 3 \\
August & 5 & 7 \\
September & 18 & 13 \\
October & 28 & 1 \\
November & 5 & 1 \\
December & 2 & 1 \\
January & 1 & 3 \\
February & 9 & 3 \\
March & 8 & 17 \\
April & 21 & 10 \\
May & 12 & 62 \\
Totals & 115 & \\
53.9 percent productive & & \\
\hline
\end{tabular}

Genetrcs 13: Mr 1928 
The number of individuals recorded fell far short of the number of young hatched and transferred from the mating jars. During the whole period of five years, only 50.6 percent or 2850 of the 5634 offspring transferred, were finally recorded. However, during the year June, 1923, to July, 1924, when better attention was given them, 55.19 percent of those transferred had their color patterns recorded. Table 2 shows the distribution of the mortality throughout that year.

TABLE 2

Number transferred compared with number recorded-year 1923-24.

\begin{tabular}{|c|c|c|}
\hline мONTH & NOUBWRS TRA NBFERRED & NUMARRS RECORDED \\
\hline July & 214 & 110 \\
\hline August & 64 & 30 \\
\hline September & 0 & 0 \\
\hline October & 154 & 61 \\
\hline November & 317 & 96 \\
\hline December & 28 & 10 \\
\hline January & 50 & 19 \\
\hline February & 313 & 173 \\
\hline March & 155 & 94 \\
\hline April & 264 & 169 \\
\hline May & 504 & 272 \\
\hline June & 1,448 & 904 \\
\hline Totals & 3,511 & 1,938 \\
\hline 55.19 percent recorded & & \\
\hline
\end{tabular}

SEGREGATION OF FACTORS IN THE MATED INDIVIDUALS

(Males on left, females on right of hyphen)

The segregation of the factors of all the individuals heterozygous for the color patterns is shown in table 3. Referring to the table; beginning at the left with the item $B l / C$, for example, all males bred gave 166 carrying $B l: 165$ carrying $C$; the females gave $192 B l: 174 C$; both males and females gave $358 B l: 339 C$, in a total of 697 gametes.

In this paper, as in a previous one (Nabours 1925), the symbol + (or $+/ t$ ) is made to serve, as it were, a double role. In tables 3 and 4, and wherever so used, + opposite a symbol for a dominant factor (for example $+/ C$ ), refers simply to the normal recessive allelomorph of that factor. In case none of the dominant factors is present, $+/+$ refers to the ensemble of indistinguishable factors that produces the mottled gray pattern, common to all species of the Tettigidae so far used in the experiments, and which has been found generally recessive to the more striking patterns. This mottled gray pattern, $+/ t$, is much more 
abundant among all the species observed in nature than are the more prominent dominant patterns. Therefore, it might be very well called the "wild type," though all the dominant patterns are also found in nature.

TABLE 3

A summary of the segregation of factors of heterozygous males and females of Telmatettix aztecus.

\begin{tabular}{|c|c|c|c|c|c|c|c|}
\hline HETRHOZxGOTBB & $\begin{array}{r}\text { BEGREGATIO } \\
\text { IN }\end{array}$ & FACTORS & $\begin{array}{r}\text { BEGREGATIO } \\
\text { IN FE }\end{array}$ & SACTORS & $\begin{array}{r}\text { SEGREGATIC } \\
\text { IN MALERB } \\
\text { COM }\end{array}$ & $\begin{array}{l}\text { FACTORS } \\
\text { FEMALES } \\
\text { D }\end{array}$ & $\begin{array}{c}\text { TOTAL } \\
\text { GAMETTEB }\end{array}$ \\
\hline$+/ C$ & $\stackrel{+}{153}$ & $\begin{array}{l}C \\
157\end{array}$ & $\stackrel{+}{213}$ & $\begin{array}{l}C \\
228\end{array}$ & $\stackrel{+}{366}$ & $\begin{array}{l}C \\
385\end{array}$ & 751 \\
\hline$+/ B l$ & $\stackrel{+}{+}$ & $\begin{array}{l}B l \\
276\end{array}$ & + & $\begin{array}{c}B l \\
96\end{array}$ & + & $\begin{array}{l}B l \\
372\end{array}$ & 780 \\
\hline$+/ H$ & $t_{67}^{+}$ & $\begin{array}{l}\boldsymbol{H}_{53} \\
\end{array}$ & $+\underset{67}{+}$ & $\begin{array}{l}H \\
\quad 60\end{array}$ & $\stackrel{+}{134}$ & $\begin{array}{l}H \\
113\end{array}$ & 247 \\
\hline$+/ R$ & $\begin{array}{l}+ \\
131\end{array}$ & $\begin{array}{l}R \\
121\end{array}$ & $\stackrel{+}{145}$ & $\begin{array}{l}R \\
167\end{array}$ & $\stackrel{+}{276}$ & $\begin{array}{l}R \\
288\end{array}$ & 564 \\
\hline$B l / C$ & $\begin{array}{l}B l \\
166\end{array}$ & $\begin{array}{l}C \\
165\end{array}$ & $\begin{array}{l}B l \\
192\end{array}$ & $C_{174}$ & $\begin{array}{l}B l \\
\quad 358\end{array}$ & $\begin{array}{l}C_{339} \\
\end{array}$ & 697 \\
\hline$B l / H$ & $\begin{array}{r}B l \\
\quad 0\end{array}$ & $\begin{array}{l}H_{1} \\
\quad\end{array}$ & $\begin{array}{c}B l \\
32\end{array}$ & $\begin{array}{l}H \\
24\end{array}$ & $\begin{array}{c}B l \\
32\end{array}$ & $\begin{array}{c}H \\
25\end{array}$ & 57 \\
\hline$B l / R$ & $\begin{array}{l}B l \\
\quad 0\end{array}$ & ${ }_{0}^{R}$ & $\begin{array}{c}B l \\
99\end{array}$ & $\begin{array}{l}R \\
124\end{array}$ & $\begin{array}{c}B l \\
99\end{array}$ & $\begin{array}{l}R \\
124\end{array}$ & 223 \\
\hline$C / H$ & $\begin{array}{l}C \\
211\end{array}$ & $\begin{array}{l}H \\
215\end{array}$ & $\begin{array}{l}C_{96} \\
\end{array}$ & $\begin{array}{l}H \\
\quad 68\end{array}$ & $\begin{array}{l}C \\
307\end{array}$ & $\begin{array}{l}H \\
283\end{array}$ & 590 \\
\hline$C / R$ & $\begin{array}{l}C \\
149\end{array}$ & $\begin{array}{l}R \\
130\end{array}$ & $C_{58}$ & $\begin{array}{l}R \\
62\end{array}$ & $\begin{array}{l}C \\
207\end{array}$ & $\begin{array}{l}R \\
182\end{array}$ & 389 \\
\hline$H / R$ & $\begin{array}{l}{ }_{3} \\
33\end{array}$ & $\begin{array}{l}R \\
39\end{array}$ & $\begin{array}{l}B \\
24\end{array}$ & $\begin{array}{l}R_{26} \\
\end{array}$ & $\begin{array}{l}H \\
57\end{array}$ & $\begin{array}{l}R \\
65\end{array}$ & 122 \\
\hline Totals & 1222 & 1147 & 1022 & 1029 & 2244 & 2176 & 4420 \\
\hline
\end{tabular}

In addition to the data summarized in the table above, there was one mating of a male $+/ C$ to a female $+/ C$. This gave $44+/ C$ and $C / C: 14$ $+/+$ individuals, a close approximation of the $3: 1$ ratio.

\section{PARTHENOGENESIS}

Parthenogenesis has been found to occur in Apotettix eurycephalus (Nabours 1919, 1925) and Paratettix texanus (Nabours and Foster, abstract, 1925). 
Virgin females of $T$. aztecus were kept by themselves from time to time to test them for parthenogenesis (NABOURS and SNyder 1924). Two or three females of a kind were placed together in each cage, except once when one female was alone.

Of 15 groups of females thus separated from males, 12 gave from 1 to 112 offspring. The first four items of table 4 are hardly worthy of a place in the table, because early death prevented complete records, but they were undoubtedly cases of parthenogenesis. In another cage, in which two females had been kept, unhatched eggs were found. The other eight items gave quite definite results. The two $+/ C$ females, (9), table 4 , that gave 49 females, $+i+$, and 53 females, $C / C$, were among the highest producers parthenogenetically (112 offspring transferred) that have been recorded among the individuals of any of the three species.

The one $C / C$ female produced parthenogenetically, item (6), in table 4, was mated to an $H / R$ male, and gave $C / H$ 5-7:C/R 3-7. Another $C / C$ female from a parthenogenetic progeny, item (9), table 4 , was mated to a $+/ B l$ male, and gave $+/ C 0-4: B l / C 2-2$.

\section{TABLE 4}

Parthenogenesis in Telmatettix astecus

(Males on the left; females on the right; figure on right of second hyphen indicates sex not recorded).

\begin{tabular}{|c|c|c|}
\hline HETEROZYGOOS FEMA & LLES & PARTHENOGENETIC OFFSPRING \\
\hline (1) & $2 \mathrm{Bl} / \mathrm{C}$ & $B l / B l 0-0-1$ \\
\hline$(2)$ & $2 B l / C$ & $B l / B l$ and $C / C 0-3-12$ \\
\hline (3) & $2+/ B l$ & $+1+0-0-1$ \\
\hline (4) & $2+/ C$ & $C / C \quad 0-0-2$ \\
\hline (5) & $2 B l / C$ & $B l / B l 0-1$ \\
\hline (6) & $2+/ C$ & $C / C \quad 0-1$ \\
\hline$(7)$ & $2 B l / C$ & $C / C \quad 0-1$ \\
\hline$(8)$ & $1+/ B l$ & $+/+0-8, B l / B l 0-8$ \\
\hline (9) & $2+/ C$ & $+/+0-49, C / C \quad 0-53$ \\
\hline$(10)$ & $3 C / H$ & $C / C \quad 0-7, H / H \quad 0-5$ \\
\hline$(11)$ & $3+/ R$ & $+/+0-1, R / R \quad 0-1$ \\
\hline$(12)$ & $3+/ C$ & $+/+0-3, C / C \quad 0-3$ \\
\hline
\end{tabular}

\section{DISCUSSION OF PARTHENOGENESIS}

PEACOCK and HARRISON (1926) have analyzed the data of the experiments showing parthenogenesis in Apotettix eurycephalus (NABours $1919,1925)$ and found from the records that all the unmated individuals that gave offspring could be traced back to hybrids from specimens of a Mexican variety crossed with individuals of a variety from Texas. They 
concluded, apparently with good reasoning, that this evidence supported their previously stated hypothesis (PEACOCK and HARRISON 1925) that parthenogenesis was consequent upon hybridity. But in Telmatettix aztecus, herein reported, the individuals that gave parthenogenetic progeny were all descended directly and exclusively from specimens captured on a very small area along Shoal Creek, Austin, Texas. None of the progeny from the Pasadena, California, specimens was mixed with those that gave offspring parthenogenetically.

However, the fact that parthenogenesis was, in these cases, confined to stocks that had come from one small area does not eliminate the possibility of hybridization, even there. This is a rather widely distributed species, and the chances for individuals of varieties to be carried by the wind, or other agencies, from place to place should not be overlooked.

An extraordinary range in markedly differing elementary color patterns, and a vast array of possibilities for combinations into pattern complexes (see plates, NABOURS 1917, 1923, 1925) are exhibited by practically all the species of the Tettigidae. They undoubtedly also have other equally, or more potent characteristics, even though less readily discernible, in just as great, or greater variety and hybrid complexity. Therefore, the results of the parthenogenetic breeding of $T$. aztecus, reported here, can hardly be made to bear on the hypothesis advanced by PEACOCK and HARRISON, certainly not in the direction of refuting it. In fact, it does not appear now just how this interesting hypothesis might be put to a critically experimental test with any of the species of the grouse locusts, from whatever small area breeding stock might be collected, for they are all probably complexly hybridized.

\section{CYTOLOGY}

In Paratettix texanus, Apotettix eurycephalus, Acrydium granulatum, Tettigidea parvipennis and other grouse locusts (Tettigidae), there have been found uniformly thirteen spermatogonial chromosomes (HARMAN 1915, RoBERTSON 1916). Cytological preparations for the study of spermatogenesis in T. aztecus, prepared with the aid of Doctor MARy T. Harman, exhibit six and seven chromosomes in the nuclei of the secondary spermatocyte divisions.

\section{SUMMARY}

1. A series of four factors for dominant color patterns and their normal recessive have been analyzed. It appears that these factors are confined to the one series, or one pair of chromosomes, and that they are alterna- 
tive, or so closely linked that no crossing over has occurred during the experiments.

2. Gynogenetic parthenogenesis occurs, in which segregation of the factors of heterozygotes takes place as in bisexual reproduction.

3. Females descended directly from individuals collected on a very small area gave offspring parthenogenetically. The results of this experiment, for the reasons given, are, therefore, neutral with respect to the hypothesis of PEACOCK and HARRISON that parthenogenesis is consequent upon hybridity.

4. The chromosome numbers have been found to be six and seven in the secondary spermatocyte division cells.

\section{IITERATURE CITED}

Harman, Mary T., 1915 Spermatogenesis in Paratettix. Biol. Bull. 29: 262-276.

Nabours, Robert K., 1914 Studies of inheritance and evolution in Orthoptera I. Jour. of Genetics 3: 142-170.

1917 Studies of inheritance and evolution in Orthoptera II and III. Jour. of Genetics 7: 1-46.

1919 Parthenogenesis and crossing over in the grouse locust Apotettix. Amer. Nat. 53: 131-142.

1923 A new dominant color pattern and combinations that breed true in the grouse locusts. Genetica 5:477-480.

1925 Studies of inheritance and evolution in Orthoptera. V. The grouse locust A poteltix eurycephalus Hancock. Kansas Agric. Expt. Sta. Tech. Bull. 17: 1-231.

Nabours, Robert K., and Foster, Martha E., 1925 Parthenogenesis in the grouse locust, Paratettix texanus Hancock. Anat. Rec. 31: 358 (Abstract).

NABOURS, ROBERT K., AND SNYDER, BERTHA, 1924 Inheritance of color patterns in the grouse locust, Telmatettix aztecus Saussure. Anat. Rec. 29: 152. (Abstract).

Peacock, A. D., and Harrison, J. W. Heslop, 1925 On parthenogenesis originating in lepidopterous crosses. Trans. Nat. Hist. Soc. Northumberland, Durham and New Castle-uponTyne. N. S., 6, Part II.

1926 Hybridity, parthenogenesis and segregation. Nature 117: 378-379.

Robertson, W. R. B., 1916 Taxonomic relationships shown in the chromosomes of Tettigidae and Acrididae; V-shaped chromosomes and their significance in Acrididae, Locustidae and Gryllidae. Jour. of Morphol. 27: 179-331. 